\title{
QUALITY OF LIFE IN AN URBAN ENVIRONMENT: A TYPOLOGY OF URBAN UNITS OF OLOMOUC ${ }^{1}$
}

\author{
Petr Kladivo, Marián Halás \\ Department of Geography, Faculty of Science, Palacký University Olomouc, Czech Republic
}

Manuscript received: January 17, 2012

Revised version: May 10, 2012

Kladivo P., Halás M., Quality of life in an urban environment: A typology of urban units of Olomouc. Quaestiones Geographicae 31(2), Bogucki Wydawnictwo Naukowe, Poznań 2012, pp. 49-60. 4 tables, 3 figs. DOI 10.2478/ v10117-012-0018-4, ISSN 0137-477X.

ABSTRACT. Studying the internal structure of cities is one of the traditional topics of geographical research. The aim of this article is to show a possible approach to the study of an objective dimension of the quality of life in an intra-urban environment focusing on detailed studies of selected indicators of the quality of life. There exist many approaches to evaluating the quality of life because it is an interdisciplinary term; we are going to focus on this issue in terms of the quality of living conditions. Using multivariate statistical methods, we are going to try a typology of an urban area in just those terms, and the results will be confronted with the perception of the quality of life by residents themselves. The area studied will be the city of Olomouc.

KEY WORDS: quality of life, housing, urban environment, intra-urban analysis, Olomouc

Petr Kladivo, Marián Halás, Department of Geography, Faculty of Science, Palacký University Olomouc, Tř́da 17. listopadu 12, 77146 Olomouc, Czech Republic; e-mail:petr-petr@email.cz,marian.halas@upol.cz

\section{Introduction}

There are two basic approaches to research on the quality of life: a subjective and an objective one (Rogerson et al. 1989, van Kamp et al. 2003, Ira 2003). A subjective (or endogenous) approach focuses on feelings, perceptions, opinions and mental states of the individuals or groups studied. An objective (or exogenous) approach tries to do research on the quality of life based on a wide range of measurable or observable indicators in an individual and an environmental dimension. Also geographers understand the term to be complex and emphasise the need to combine both approaches mentioned above (Pa- cione 1982, Ira 2008, Massam 2002) and study it at all geographical levels: from the global level of countries (Henderson et al. 2000), through lower territorial units (Boyer \& Savageau 1981) to cities and villages (Pacione 1986, Schneider 1974, Andráško 2008).

The first works on the quality of life, whether from a psychological or an environmental point of view, appeared in the 1960s, others were introduced in the 1970s by geographers studying spatial differences in social indicators (Smith 1973, Knox 1975) and focusing on individual qualityof-life indicators, such as income, property, employment, an aspect of housing and the quality of the environment in a place of residence, physical

\footnotetext{
$1 \quad$ The article is an outcome of project no. KJB300860901 of the Grant Agency of the Academy of Sciences of the Czech Republic "Qualitative methods and synthesizing graphical methods in approximation, projection and modelling of geographical phenomena", and of project no. P404/11/1811 of the Grant Agency of the Czech Republic "Urban and suburban quality of life: a geographical perspective".
} 
and mental health, education, social belonging, and opportunities for recreation and spending free time. By examining those indicators at various spatial scales, from international to intra-urban, and by analysing geographical differences in living conditions, scholars try to answer the question of "who gets what and where" (Smith 1979). Also Pacione (1982) argues that the meaning of the term 'quality of life' differs with the context. It is generally used in connection with selected indicators of living conditions or the environment (air and water pollution, or the quality of housing), or some attribute of the population, such as health or education.

The subjective approach (subjective dimension) involves two main directions. The first is a detailed research on the socio-demographic background of a city, which is very often an analysis of the so-called factor ecology of the city. It allows an assessment of the quality of life in areal units of the city based on the distribution of inhabitants and their attributes. The second is a research on living conditions in an urban area, which is the topic this article focuses on. This direction corresponds to that of Helburn (1982), who argues that the quality of life is influenced by the environment people live in, and he looks for those of its attributes that bring satisfaction and happiness. The whole concept lies in the choice of indicators giving an objective assessment of the quality of living conditions in the city. Van Kamp et al. (2003) argue in their article dealing with the concept of environmental quality of life in an urban environment that this topic has been very popular in recent years not only with the general public, but also in the political sphere, e.g. while planning land use in cities.

In this article we will focus on a geographical approach, whether in data collection, their processing, or interpretation. We support the claim that most of the problems connected with people's lives have also a geographical dimension (Frazier 1982), which is a prerequisite for the application of geography in our research, because the quality of life changes from place to place and from person to person (Andráško 2005). Each individual lives in his or her own area, and there are also areas where people satisfy their everyday needs. It is those areas that become a subject of geographical research; it is mostly residential formations which are not, however, homogeneous, and therefore display spatial differences in the quality of life. The strength of geography is its ability to point out and examine differences among areas from a quality-of-life point of view.

\section{Methodology, choice of indicators, data sources}

The first step in researching living conditions is a choice of appropriate indicators. Pacione (1982) and Andráško (2007) first set key spheres of the quality of life. They consider that the crucial ones are the environmental, social and cultural, economic, and institutional areas; then a choice of suitable characteristics should follow. Like Rogerson et al. (1989), Schneider (1974), Baeriswyl et al. (1996), or Civerolo et al. (2007), we focus on social indicators, such as the level and quality of housing, availability of services (education, health and commercial facilities, etc.) transport services, and security, which are supplemented with selected environmental indicators dealing with air quality, saturation with green areas, etc. An important role in choosing the indicators is played by the availability of data for all units of the internal division of a territory.

We will try to create a wide set of variables to which we will apply (after Węcławowicz 2003 and Chojnicki \& Czyż 1976) multivariate statistical methods (the principal components method, cluster analysis) to understand interactions and relationships between variables. At the same time we will make a typology of space based on the quality of living conditions. The main methods we chose give the article the character of a quantitative study down to the level of basic settlement units (urban districts) of Olomouc, which are thus the primary spatial units of the analysis. Such small spatial units usually mean less distortion, thus avoiding the problem of so-called ecological fallacy, but there could be a problem with data availability. Such an approach is quite common in the literature because the quality of life is usually examined in the administratively defined area of a city (e.g. Ira 2003, 2005 on the territory of Bratislava). The results of the quantitative research will be briefly compared with subjective perceptions of the quality of life through field- 
work data. To ensure the conclusive evidence of a questionnaire survey, $1 \%$ of the population of productive and post-productive age was chosen. The 2001 Population and Housing Census revealed that 86,900 people of this age lived in Olomouc, which would translate into approximately 900 respondents. Ultimately, 901 filled questionnaires were included in the analysis.

\subsection{Environmental indicators}

Among the most important environmental indicators is air quality, the basis of the environment with a direct impact on humans, a nonreplaceable part of human life connected with a fundamental physiological need - to breathe. The impact of air quality on the quality of human life is in fact undeniable. The essential problem is that unlike other types of pollution (water, soil), it is difficult to protect people from its effects. Due to industrial activities, transport and other potential sources, the most endangered group is residents of big cities who can be (and many studies made by the World Health Organization, such as Krzyżanowski 2010, prove that they actually are) exposed to excessive concentrations of air pollutants. Air pollution monitoring and study should thus be priority areas for cities and municipalities. We evaluated the air quality in Olomouc on the basis of data provided by the municipal government which were processed for "Air Quality Management System for Olomouc City". We considered pollution by nitrogen oxides, sulphur and dust. For our purposes, when we assessed the quality of life in Olomouc by selected indicators in basic settlement units, we had to digitise data on air pollution to ensure that the tabulated data acquired would not impede the multivariate analyses we carried out.

One of the major indicators of the quality of the urban environment is the presence and accessibility in it of so-called green areas. Generally speaking, they include not only vegetation elements (trees, lawns, flowerbeds, bushes, etc.), but also inanimate elements (roads, staircases, terraces, pools, walls, benches, shelters, playgrounds, sandpits, etc.). Green areas are mainly parks and landscaped areas, a forest, cemeteries, parkways, but also gardens at individual
Table 1. An overview of greenery in Olomouc

\begin{tabular}{|c|r|c|c|}
\hline $\begin{array}{c}\text { Type of } \\
\text { greenery }\end{array}$ & ha & $\begin{array}{c}\text { Proportion } \\
\text { of total } \\
\text { greenery } \\
\mathbf{( \% )}\end{array}$ & $\begin{array}{c}\text { Proportion } \\
\text { of total city } \\
\text { area }(\mathbf{\%})\end{array}$ \\
\hline Forest & $1,383.1$ & 69.6 & 13.4 \\
\hline Parks & 28.4 & 1.4 & 0.3 \\
\hline Gardens & 543.8 & 27.4 & 5.3 \\
\hline Other & 31.2 & 1.6 & 0.3 \\
\hline Total & $1,986.5$ & 100.0 & 19.3 \\
\hline
\end{tabular}

Source: Municipal government, own research.

buildings or dispersed greenery including single trees. The greenery is part of the environment of the city and its urban structure and fulfils especially ecological, recreational, cultural and aesthetic functions (Supuka 1991). The ecological function is provided by trees and plants through their physiological processes and they influence the climate of the city and have a positive impact on its air quality. Among the capabilities of trees is the absorption of micro-particles, such as airborne particles, which reduces their concentration in the air (Nowak et al. 2006). We can also add an economic function because care for greenery requires new jobs; in addition, a 'green' environment influences the quality of housing, which is connected with a demand for such houses or flats and with their prices.

\subsection{Social indicators}

The quality, development and spatial differences in the housing stock are among the basic indicators of a functional structure of a city influencing many social phenomena in the urban environment. Housing features in our study because we treat the quality of the housing stock as an indication of the quality of living conditions. On the example of Olomouc we can see how the city has developed since the end of the $19^{\text {th }}$ century. Until then the city was a major fortress where all life took place inside the walls. Any construction and related development was conditioned and radically limited by its military function until 1886 when its fortress status was cancelled (and fortifications ware partially demolished). Figure 1 shows a typology of individual parts of the city in terms of the quality of housing. The typology 
is based on the housing stock data from the 2001 Population and Housing Census.

Building development connected with the cancellation of the fortress status, its gradual spatial and population growth, and changes in housing development in the $20^{\text {th }}$ century have been the main factors determining the current housing stock in Olomouc. The 26 parts of the city can be classified into five basic groups according to its form. With the exception of the city centre (the Olomouc-město quarter), their contemporary character is influenced by the date when the parts were connected to Olomouc. Those which were integrated very early have merged with the centre and the form of many of them has been influenced by the urbanism and architecture of the second half of the $20^{\text {th }}$ century. By contrast, the parts connected later have usually kept their rural nature and we can notice features of suburbanisation there. The character of housing development changed in the 1990s when the implementation of housing estate projects (typical of Olomouc since the 1960s) finished and first plans for modern housing started to appear. In areas that were not built up, houses began to grow, blocks of flats gradually underwent revitalisation, and flats in the centre - gentrification. There have also been issues of imperfect land-use planning, for example lacking parking places and their location (which can also be a result of the less effective planning in the past). The housing stock of the city has enlarged in the last few years thanks to many development projects, which include the construction of new blocks of flats or houses which are either imaginative, "from a catalogue", or low-cost. Thus, the share of large-panel houses has started to decrease slowly. Indicators of the housing stock quality can be divided into qualitative categories, according to age, living space per person, and location (in panel, brick or family houses, etc.).

The next indicator we consider important is security in the city. To analyse it, we used data provided by the municipal government, more specifically a seven-year set of information (2001-2007) about all streets of Olomouc with the number of crimes more than 20 per year. Again, these data were digitised for our purposes. Every street was assigned to an appropriate basic residential unit; if it goes through more units, criminality was calculated in an appropriate proportion.

In the following part of the research we focused on the availability of services. The first is education, because education and the will to learn is one of the most important human activities in general. It is obvious that access to education, whether in pre-school, school or postschool age, is a key aspect of the quality of life. The level of education shows how much a region is developed, and it is not only the accessibility of educational institutions which determines its level of development, but also their quality. The availability of data on this issue is very good. We used school registers which can be found on the website of the Ministry of Education, Youth and Sports, the database of public schools established by the city of Olomouc, or one by Olomouc Region, which is also published on the website of the municipal government's Department of Education.

The next characteristic we considered was the availability of health care. It includes a lot of specialised services and facilities. Their quality and availability are important factors and indicators of the quality of life (Hanušin et al. 2000). In our research we used data from the register of the Ministry of Health.

Concerning commercial facilities, we focused on the location of selected retail outlets in Olomouc. To meet everyday needs, an available grocery is essential, and the next indicator from this field is clothes shops. After 1989, the retail network has become more concentrated, and it is this concentration of facilities and their capacity that influence the quality of life of inhabitants, especially in cities. An increase in the number of retail units and a gradual expansion of retail space as a result of a loosening of the economy, its decentralisation and changes in ownership are typical processes whose growth is associated with the post-1989 era. Gradually, large shops have appeared, very often in place of small shops, which are typical of the food industry. Data on the retail network come from our own field investigation made in 2009.

The analysis also embraced the availability of a bank, its branch or a cash machine, and a post office; we also considered the availability of restaurants. Data come again from our own field in- 

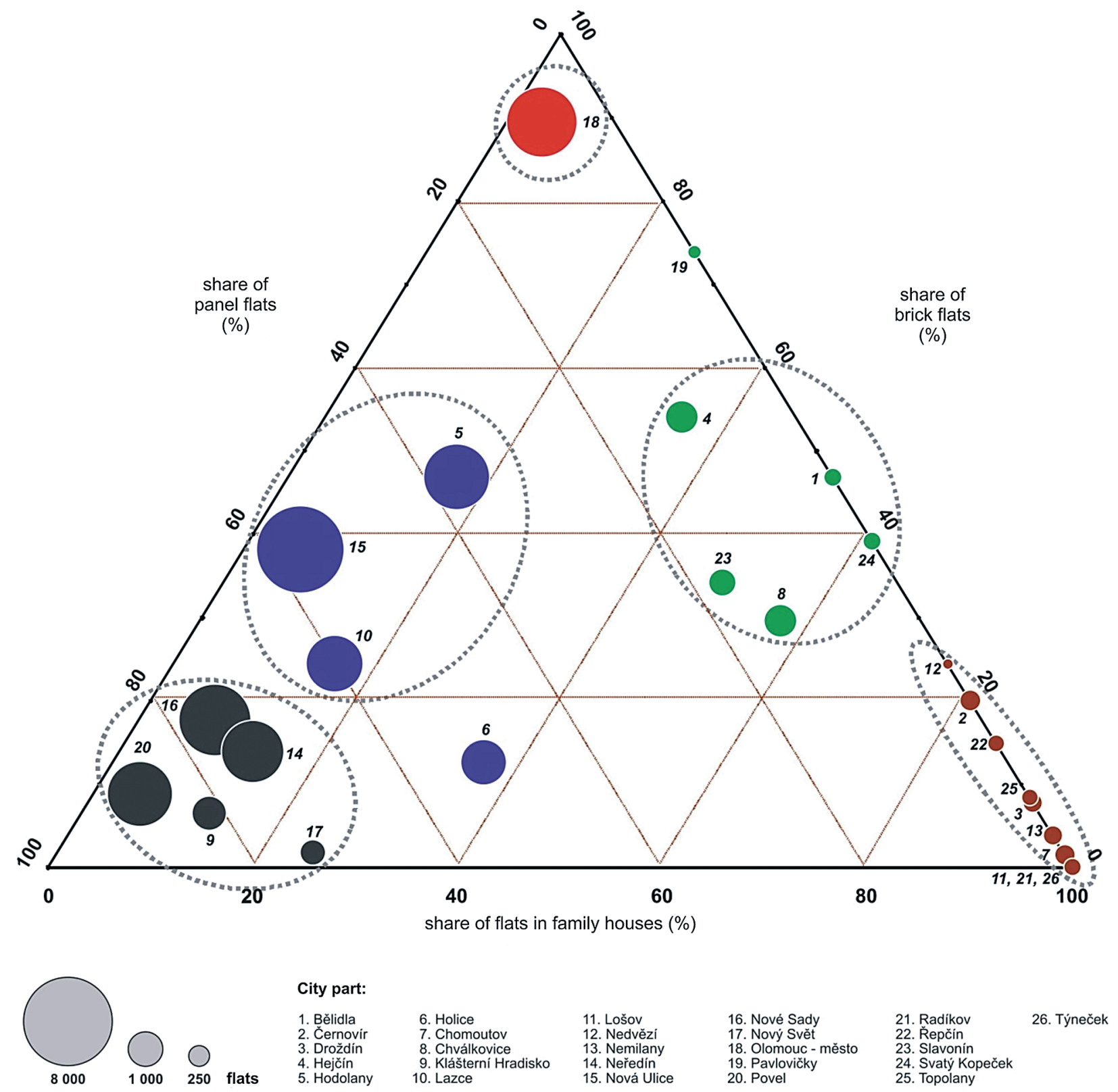

Fig. 1. Ossan triangle for the Olomouc city parts - the structure of the housing stock. Source: own elaboration based on the 2004 ČSÚ database.

vestigation. As with the food and clothes stores, all the facilities were assigned to basic settlement units.

Accessibility of the city centre by public transport, either by bus or tram, can be an indicator of the quality of transport connections (if there are more stops in a primary settlement unit, data are averaged). To find data on specific connections, we used the database of the Integrated Transport System IDOS.

\section{The principal components method}

As was already mentioned in the opening chapters of this work, a suitable method for studying the internal structure of a city, not only from the quality-of-life point of view, is principal components analysis. Its application will allow us to reduce the high number of input variables thanks to hidden links between them, and subsequently to make a typology of individual spatial units 
based on cluster analysis. As input data we will use the variables described in the previous chapters; their list can be found in Table 2 .

A $82 \times 30$ matrix entered the analysis, where the 82 lines represent individual basic settlement units and the 30 columns stand for individual variables. The variables were studied in more detail and we tested normality using the $\chi^{2}$ test and the Kolmogorov-Smirnov test. If they did not meet this condition, we proceeded to logarithmic transformations to keep the normality.

The next step included the principal components analysis itself, which we made in the Statistica software interface. As an initial result, we received 30 new components, mutually orthog- onal (see Table 3 where the ten most important components can be found) and characterised by an eigenvalue and the proportion of the original variance accounted for. Using the so-called Kaiser rule (which recommends considering components whose eigenvalue is higher than or equal to one), we extracted ten principal components out of the total of 30 which accounted for $79.5 \%$ of the original information.

In the next step we identified individual components based on factor scores of the input variables in relation to these newly derived components. The results can be found in Table 4, which contains the relationship of the original variables to the ten most important components with the

Table 2. Input variables used in the principal components analysis.

\begin{tabular}{|c|c|}
\hline No. & Variable - characteristics \\
\hline 1 & Flats of 1st and 2 nd category - proportion of flats of 1 st and 2 nd category in total number of flats \\
\hline 2 & Flats of 4 th category - proportion of flats of 4 th category in total number of flats \\
\hline 3 & Family houses - proportion of flats in family houses in total number of flats \\
\hline 4 & Flats built before 1945 - proportion of flats built before 1945 in total number of flats \\
\hline 5 & Flats built 1946-1970 - proportion of flats built between 1946 and 1970 in total number of flats \\
\hline 6 & Flats built 1971-1990 - proportion of flats built between 1971 and 1990 in total number of flats \\
\hline 7 & Flats built 1991-2001 - proportion of flats built between 1991 and 2001 in total number of flats \\
\hline 8 & Size of living area - average number of $m^{2}$ of living space per person \\
\hline 9 & Number of persons per room - average number of persons per habitable room \\
\hline 10 & Size of flat-average number of rooms in flat \\
\hline 11 & $\mathbf{P M}_{10}$ - average annual concentration of $P M_{10}$ particulates in the area \\
\hline 12 & $\mathrm{SO}_{\mathbf{x}}$ - average annual concentration of $\mathrm{SO}_{x}$ in the area \\
\hline 13 & $\mathbf{N O}_{\mathbf{x}}-$ average annual concentration of $\mathrm{NO}_{x}$ in the area \\
\hline 14 & Dentists - average number of dentists per 1,000 inhabitants \\
\hline 15 & Pharmacies - average number of pharmacies per 1,000 inhabitants \\
\hline 16 & Groceries - average number of groceries per 1,000 inhabitants \\
\hline 17 & Clothes shops - average number of clothes shops per 1,000 inhabitants \\
\hline 18 & Gynaecologists - average number of gynaecologists per 1,000 inhabitants \\
\hline 19 & Paediatricians - average number of paediatricians per 1,000 inhabitants \\
\hline 20 & General practitioners - average number of general practitioners per 1,000 inhabitants \\
\hline 21 & Public transport - temporal accessibility of the city centre by public transport \\
\hline 22 & Restaurants - average number of restaurants, clubs, bars, etc. per 1,000 inhabitants \\
\hline 23 & Restaurants offering lunch menu - average number of restaurants offering lunch menu per 1,000 inhabitants \\
\hline 24 & Flats in large-panel houses - proportion of flats in large-panel houses in total number of flats \\
\hline 25 & Flats in brick houses - proportion of flats in brick houses in the total number of flats \\
\hline 26 & Primary schools - number of seats in a primary school per 1,000 children aged 6-14 \\
\hline 27 & Nursery schools - number of seats in a nursery school per 1,000 children aged 3-5 \\
\hline 28 & Criminality - number of crimes per 1,000 inhabitants \\
\hline 29 & Greenery - proportion of greenery in total area of basic settlement unit \\
\hline 30 & Banks - number of bank branches, cash machines and post offices per 1,000 inhabitants \\
\hline
\end{tabular}


Table 3. Ten most important components.

\begin{tabular}{|c|c|c|c|}
\hline Component & Eigenvalue & $\begin{array}{c}\text { Proportion } \\
\text { of original } \\
\text { variance } \\
\text { accounted } \\
\text { for } \mathbf{( \% )}\end{array}$ & $\begin{array}{c}\text { Cumulative } \\
\text { proportion } \\
\text { of variance } \\
\text { accounted } \\
\text { for (\%) }\end{array}$ \\
\hline 1 & 4.51 & 15.04 & 15.04 \\
\hline 2 & 3.72 & 12.40 & 27.45 \\
\hline 3 & 3.29 & 10.95 & 38.40 \\
\hline 4 & 2.94 & 9.81 & 48.21 \\
\hline 5 & 2.08 & 6.94 & 55.15 \\
\hline 6 & 1.89 & 6.29 & 61.43 \\
\hline 7 & 1.68 & 5.61 & 67.04 \\
\hline 8 & 1.40 & 4.67 & 71.71 \\
\hline 9 & 1.22 & 4.07 & 75.78 \\
\hline 10 & 1.12 & 3.73 & 79.51 \\
\hline
\end{tabular}

Source: own elaboration.

absolute value of the correlation coefficient of 0.5 and higher.

The first and most important component from the point of view of the proportion of the original variance accounted for characterises the spatial units of the city in terms of the size of a flat and its

Table 4. The most important components extracted and the correlated variables $(|\mathrm{r}|>0.5)$.

Component 1 - Size and quality of housing stock

\begin{tabular}{|c|c|}
\hline Size of flat & 0.829 \\
\hline Size of living area & 0.773 \\
\hline Family houses & 0.748 \\
\hline Brick houses & 0.718 \\
\hline Flats of 1st and 2nd category & 0.650 \\
\hline Flats built before 1945 & 0.564 \\
\hline
\end{tabular}

Component 2 - Selected services and security

\begin{tabular}{|c|c|}
\hline Banks & 0.670 \\
\hline Restaurants with lunch menu & 0.626 \\
\hline Restaurants & 0.621 \\
\hline Criminality & 0.617 \\
\hline Average number of persons per living area & 0.558 \\
\hline Component 3 - Air quality \\
\hline $\mathrm{NO}_{x}$ & -0.726 \\
\hline $\mathrm{PM}_{10}$ & -0.592 \\
\hline SO $_{x}$ & -0.510 \\
\hline Public transport $^{2}$ & 0.580 \\
\hline Component 4 - Health care \\
\hline Flats built from 1971 to 1990 & 0.738 \\
\hline Flats in large-panel houses & 0.680 \\
\hline General practitioners & 0.601 \\
\hline Dentists & 0.592 \\
\hline Component 5 - School system \\
\hline Nursery schools & 0.743 \\
\hline Primary schools & 0.727 \\
\hline
\end{tabular}

Source: own elaboration. quality. Districts with high values of factor scores are areas with a high proportion of flats in brick or family houses and, in addition, with the largest living area per person. Units with low values show an opposite trend, which is mainly the case of Olomouc neighbourhoods (see Fig. 2).

The second component is connected with variables characterising selected services - the availability of restaurants or branches of banks, post offices and cash machines. We should also not forget the selected indicator of security - the proportion of crimes per person. The component also covers the dominance of the city centre and its surroundings over the suburbs. The third component is represented by air quality and accessibility of the city centre. The worst situation in terms of pollution can be seen in the city centre, along major roads, and in industrial localities. The more distant the unit from the city centre, the better its situation. The fourth and fifth components are connected with health care facilities and school services.

\section{Cluster analysis and a final typology}

Using the factor scores of the individual basic settlement units in relation to those ten components, we made a final typology of the units. Six basic types (see Fig. 3) were identified on the basis of cluster analysis involving a 82 (BSU) x 10 (components) matrix producing the factor scores of the individual spatial units. The optimal number of clusters was tested by the program Statistica using a few simple methods (dendrograms and fusion coefficients).

\subsection{Generalised form of individual types}

\section{Type A}

This category covers the central parts of the city. Units identified in this cluster show similarities mainly in the structure of the housing stock (flats in brick houses predominate) and its age. They are also areas with the best commercial facilities in Olomouc and the best services offered, for example the health care system. The category covers the basic settlement units of the Olomoucměsto district and others in its close vicinity. The 


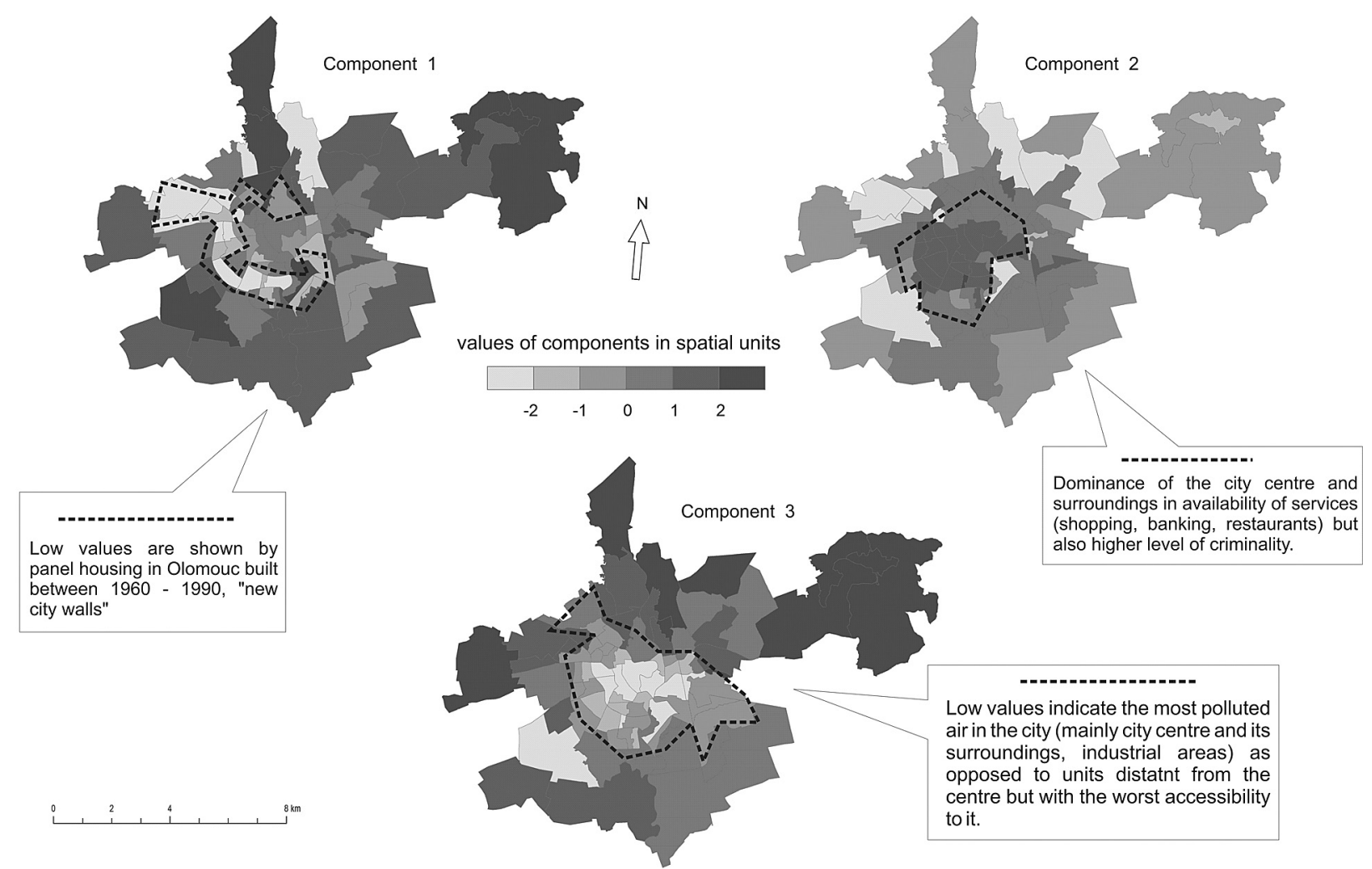

Fig. 2. Values of the main components in the basic settlement units. Source: own elaboration.

type of flats that predominate here are located in brick houses, some of the oldest in the city, which is obvious in the case of a historical centre; the housing development is from the end of the $19^{\text {th }}$ and the beginning of the $20^{\text {th }}$ century, when construction expanded in the area of the former fortifications and even in front of them.

\section{Type B}

This type covers units in the neighbourhood of the previous category, which are characterised by high population density; they are mainly those creating an incomplete whorl from the west (settlements I. Pětiletky, Stiborova, Stupkova, Tererovo náměstí) through the south (Pionýrská, Povel, Nové Sady, Družební) to the southeast (Nový Svět, Holice) around the central parts of the city. In the north, this whorl is not closed, only the settlements Lazce and Černá cesta belong here. The common features are the dominance of flats in large-panel houses, an above-average number of persons per flat, and a smaller living area per person. This category has the lowest value of the first component, which suggests below-average values of the variables connected with it. These settlement units, built from the 1960s to the early 1990s, are of lower quality in terms of the housing stock.

\section{Type C}

This type includes units located on the edge of the compact city or in its vicinity. Their characteristic feature is a lot of undeveloped land where new development projects have begun and they have started to unite with the compact city. The weaknesses of this type is low availability of services and lack of schools and groceries.

\section{Type D}

Like the previous type, this category covers units in the peripheral parts of the city which, however, differ from type $\mathrm{C}$ in a better offer of services. Here belong the cores of municipalities integrated into Great Olomouc in 1919, such as Chválkovice, Pavlovičky, Bělidla, Řepčín or Černovír, which have not been affected by the construction of largepanel houses. The housing stock therefore mainly consists of flats in brick houses. 


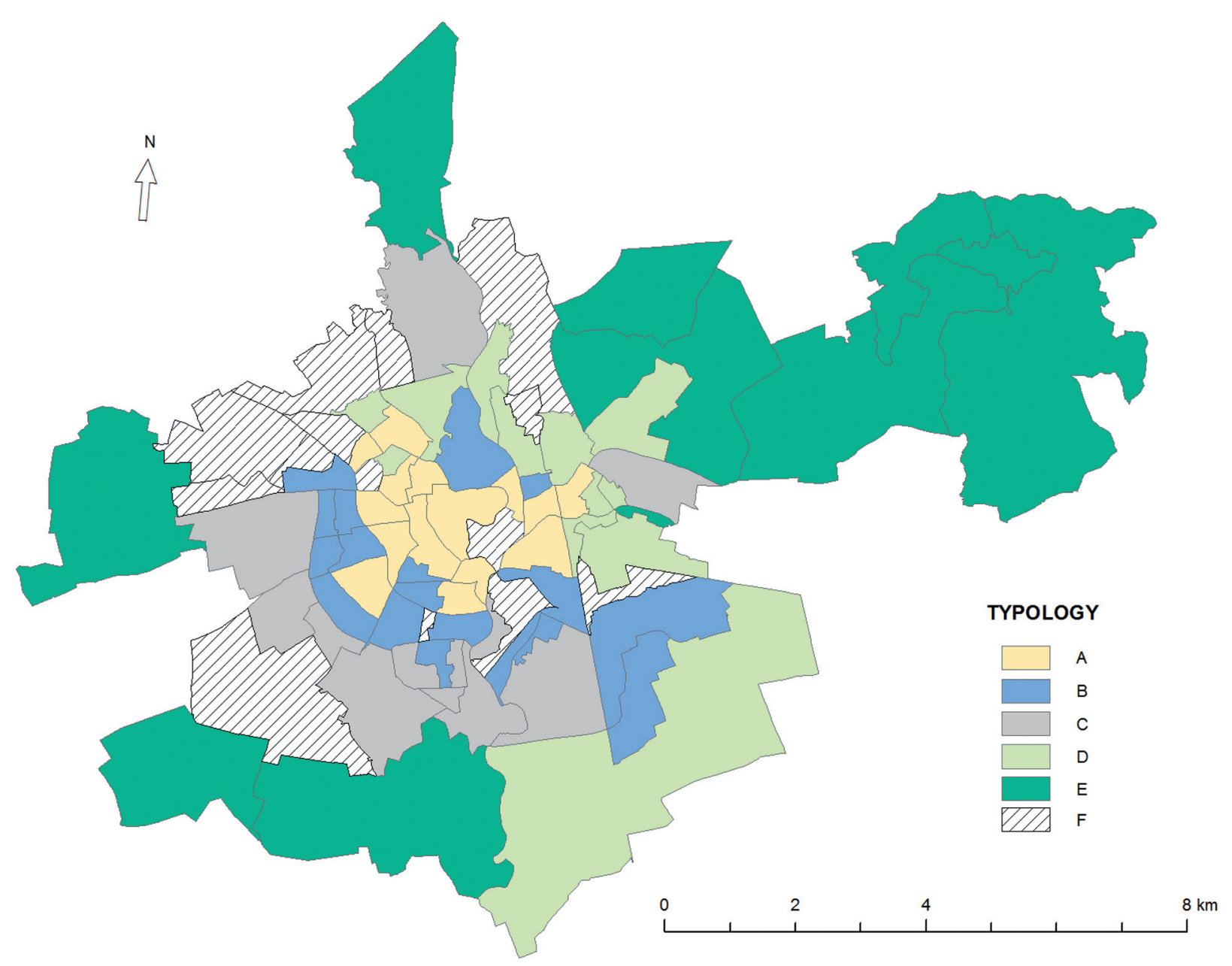

Fig. 3. Typology of basic settlement units of Olomouc based on the quality of living conditions. Source: own elaboration.

\section{Type E}

This type includes mainly units predominantly rural in character, municipalities integrated with Olomouc as the last, outside the current compact city. They are characterised by a relatively high standard of housing as expressed by a high proportion of flats in family houses and in the size of flats. Simultaneously, this type has a high proportion of greenery and the least polluted air in Olomouc. These indicators suggest that those are localities of high quality. The evaluation slumps with an analysis of city-centre accessibility in terms of time, because these units have the worst figures, especially the northeast units of Svatý Kopeček, Droždín, Lošov and Radíkov. The situation is also relatively unfavourable in shopping and other services, the problem is predominantly with commercial facilities, which is caused by a low number of inhabitants in those units.

\section{Type $\mathbf{F}$}

The last category includes units that are specific in some aspects. In the northern or northwestern parts of the city there are areas with no permanent residents because those are locations of several industrial parks (such as an old factory of Moravské železárny in Řepčín, or Farmak in Černovír), agricultural land, or military grounds (Šibeník, or Neředín-u-pevnůstky). For the same reason, this category includes also the basic settlement units of Holická and Hodolanyprůmyslový obvod, both of an industrial character. As specific can also be seen areas of big shopping centres, with a minimum of permanent residents and most variables reaching extreme values (especially in the area of the facilities). This is the case of the units Pražská-západ (a Globus shopping centre) and U Hvězdárny (a Haná shopping centre). The next specific units are 17. listopadu, which is basically a University campus 
with accommodation facilities, and Schweitzer, which has a low number of inhabitants because it lies in the middle of two settlements.

\section{Discussion and conclusion}

The final typology will now be briefly compared with the results of the questionnaire survey carried out in 2008. Lošov, Radíkov, Svatý Kopeček, Droždín, and Nemilany are the toprated city parts of Olomouc, not only in terms of most of partial indicators (subjective, assessed by the respondents), but also by preferential votes given. In the classification based on the quality of selected living conditions, they all belong to one type (E), which includes units of a predominantly rural character, the last to be integrated with Olomouc and found outside the current compact city. Their common feature is a relatively high standard of housing, which can be seen in a high proportion of flats in family houses and their size. Simultaneously, this type has a high proportion of greenery and the least polluted air in Olomouc. These indicators suggest that those localities are of high quality.

The survey also contained questions about the best and the worst localities in the city in terms of the quality of life. Each respondent could choose three localities; he could name an urban area, a housing estate, or a street. Such data expressing how a place is perceived and identifying highly regarded or least favoured areas are very helpful and valuable for understanding the perception of urban space. The results offer a very interesting confrontation of the real (objective) dimension of the quality of life with a subjective one.

Most of the respondents said that the best locality from the quality-of-life point of view was Svatý Kopeček. This answer was given by onethird of those polled, and 165 of them ranked it first. The question is what led Olomouc inhabitants to this answer; evidently, the attractiveness of this place, which provides its residents with high-quality housing, easy access to nature, clean air, and a good condition of public facilities, prevailed over the bad accessibility of the city centre, services and the scarcity of shops. The second-ranked area was the city centre (180 respondents). The central part of the city was pre- ferred by residents of peripheral units with their image of the high-quality or even luxury living it offered, good availability of all services, and cultural life. On the other hand, people living in the city centre and its close vicinity considered this unit to be the worst, so this area was also the second most unpopular location. The next positions in the ranking were occupied by villa quarters, more specifically Nová Ulice, Neředín and Lazce, with the same number of 100 votes. The next units were quarters with a high proportion of family houses and a highly rated quality of the environment: Bělidla, Chválkovice and Hejčin. We were very surprised by the ranking of areas where construction, development projects, or suburban processes have taken place recently. Those units, except for Slavonín (e.g. Topolany, Nemilany or Týneček), were hardly preferred at all: they only got between 10 and 20 votes. This, however, can be distorted by two facts: they consist of a relatively large number of smaller localities (the votes are 'spread'), and many of these areas are not widely known.

Concerning negative votes, Nový Svět was the top choice with 230 answers. This is caused primarily by Přichystalova street, very often mentioned separately (more than 50 answers), where a community of socially excluded population lives. This street, which separates Nový Svět from Hodolany, does not make so bad an impression at first sight, but in the side streets towards the Olomouc-Prostějov railway there are many decaying houses. Nový Svět was followed by the city centre, as mentioned above, and Hodolany, Černovír and Holice, which lie in the surroundings of industrial parks, so this ranking was no surprise, and neither was a negative assessment of Povel, Neředín (very often described by respondents as "mačkalov", a crowded place) and Lazce, mainly because of the quality of housing and the appearance of these settlements.

In the first part of this study we employed a set of 30 variables expressing the quality of living conditions in the city of Olomouc for all its 82 basic settlement units. We made their typology by this criterion using multivariate analysis. The result was six types of city units, one of which represented specific urban areas, such as industrial or military areas, a shopping centre or a campus. We managed to prove spatial dif- 
ferences in living conditions not only between the compact city and its surroundings, but also within the compact city itself, whose urban units are divided into four categories. The difference between them lies, generally speaking, mainly in the structure of the housing stock and in the availability of services.

Our aim was to assess the inner structure of the city and its relationship to spatial differences in the quality of life of the inhabitants. The whole research was based on the choice of indicators of the quality of living conditions, which suggests the possibility of a future extension of the topic by adding new aspects we have not considered in this work. Using the questionnaire survey, we tried to find what areas were perceived by their residents as attractive in terms of the quality of living, and which were seen in a negative way. The conclusion was that type E we identified, or the units it contains, was perceived most favourably. There was a discrepancy in the perception of the city centre, which was assessed differently by its residents and by people from "outside". A negative assessment was given to districts of type B, especially in the evaluation of their appearance, presence of greenery and the quality of housing. Generally we can say that an aboveaverage evaluation was given to types $A$ and $D$, mainly because of their good availability of services and living in a combination of brick and family houses. It is the quality of housing, attractiveness of the environment and the availability of services that are crucial indicators of the quality of living conditions, according to our respondents.

\section{References}

ANDRÁŠKo I., 2005. Dve dimenzie kvality života v kontexte percepcií obyvatelov miest a vidieckych obcí (Two dimensions of the quality of life as perceived by rural and urban populations). In: Vaishar A. \& Ira V. (eds), Geografická organizace Ceska a Slovenska v současném období. Institute of Geonics, Academy of Sciences CR, Brno: 6-13.

ANDRÁŠKo I., 2007. Vnútorná štruktúra mesta z hladiska kvality života (Intra-urban structure from the quality-of-life point of view). Dissertation. Slovak Academy of Sciences, Bratislava.

ANDRÁŠKO I., 2008. Hlavné komponenty spokojnosti s kvalitou životných podmienok v mestských štvrtiach Bratislavy (Major components of satisfaction with the quality of living conditions in Bratislava city districts). In: Kallabová E., Smolová I. \& Ira V. (eds), Změny regionálních struktur České republiky a Slovenské republiky. Institute of Geonics, Academy of Sciences CR, Palacký University Olomouc, Brno: 74-79.

Baeriswyl I., De Buman A., Fallot M.J., Hertig M.J., Roten M. \& RuFfieux D., 1996. Local climate and pollution in the city of Fribourg (Switzerland). Institute of Geography, University of Fribourg.

BOYER R. \& SAVAgeau D., 1981. Places rated almanac: Your guide to finding the best places to live in America. Prentice Hall, New York.

CHоjNICKi Z. \& CZYŻ T., 1976. Some problems in the application of factor analysis in geography. Geographical Analysis, 8: 41-53.

Civerolo K., Hogrefe C. \& Lynn B., 2007. Estimating the effects of increased urbanization on surface meteorology and ozone concentrations in the New York City metropolitan region. Atmospheric Environment, 41/9: 1803-1818.

FrAZIER J.W., 1982. Applied geography: A perspective. In: Frazier J.W. (ed.), Applied geography: Selected perspectives. Englewood Cliffs, Prentice-Hall: 3-22.

Hanušin J., Huba M., Ira V., Klinec I., Podoba J. \& SzÖllös J., 2000. Výkladový slovník termínov z trvalej udržatel'nosti (One-language dictionary of sustainability terms). Society for Sustainable Living, Bratislava.

HeLbURN N., 1982. Geography and the quality of life. Annals of the Association of American Geographers, 72: 445-456.

Henderson H., Lickerman J. \& Flynn P., 2000. Calvert-Henderson quality of life indicators: A new tool for assessing national trends. Calvert Group, Bethesda.

IRA V., 2003. Changing intra-urban structure of Bratislava city and its perception. Geografický časopis, 55: 91-107.

IRA V., 2005. Quality of life and urban space (Case study from city of Bratislava, Slovakia). Europa XXI, 12: 83-96.

Ira V. (ed.), 2008. L'udia, geografické prostredie a kvalita života (People, the geographical environment and the quality of life). Geographica Slovaca, 25, Slovak Academy of Sciences, Bratislava.

KLADIvo P., 2011. Socio-demographic structure of Olomouc from the point of view of the quality of life. Acta Universitatis Palackianae Olomucensis - Geographica, 42(2) (in print).

Kladivo P., FŇUkal M., Halás M., Klapka P., Ptáček P., SzcZYRBA Z. \& TouŠEK V., 2009. Vybrané aspekty kvality života Olomouce a blízkého zázemí (Selected aspects of the quality of life in Olomouc and its hinterland). In: Lipský Z., Popková K., Poštolka V. \& Šmída J. (eds), Geodny Liberec 2009. Liberec: 87-94.

KLAdivo P. \& ŠIMÁČEK P., 2011. Vývoj a prostorové rozložení bytového fondu Olomouce (Development and spatial distribution of the Olomouc housing stock). Urbanismus a územní rozvoj, 14(2): 32-38.

KNox P.L., 1975. Social well being: A spatial perspective. Clarendon Press, Oxford.

KRZYŻANOWSKI M., 2010. WHO guidelines for indoor air quality: Selected pollutants. WHO, Copenhagen.

Massam B.H., 2002. Quality of life: Public planning and private living. Progress in Planning, 58: 141-227.

Nowak D.J., Crane D.E. \& Stevens J.C., 2006. Air pollution removal by urban trees and shrubs in the United States. Urban Forestry \& Urban Greening, 4(3-4): 115-123.

PACIONE M., 1982. The use of objective and subjective measures of quality of life in human geography. Progress in Human Geography, 6: 495-514. 
PACIONE M., 1986. Quality of life in Glasgow: An applied geographical analysis. Environment \& Planning, A, 18: 1499-1520.

Rogerson R.J., Findlay A.M. \& Morris A.S., 1989. Indicators of quality of life: Some methodological issues. Environment and Planning, A, 21: 1655-1666.

SCHNEIDER M., 1975. The quality of life in large American cities: Objective and subjective social indicators. Social Indicators Research, 1(4): 495-509.

SмITH D.M., 1973. The geography of social well being in the United States: An introduction to territorial social indicators. McGraw Hill, New York.

Sмiтн D.M., 1979. Inner-city deprivation: Problems and policies in advanced capitalist countries. Geoforum, 10: 297310 .
Supuka J., BenčaŤ F., Bublinec E., Gáper J. \& Hrubík P., 1991. Ekologické princípy tvorby a ochrany zelene (Ecological principles of greenery protection). Slovak Academy of Sciences, Bratislava.

van Kamp I., Leidelmeijer K., Marsman G. \& De Hollander A., 2003. Urban environmental quality and human wellbeing: Towards a conceptual framework and demarcation of concepts; a literature study. Landscape and Urban Planning, 65: 5-18.

WęCŁAWOWICZ G., 2003. Geografia społeczna miast - zróżnicowanie spoteczno-przestrzenne (The human geography of cities socio-spatial differences). PWN, Warszawa. 